\title{
Literacies in Early Modern England
}

\author{
EVE RACHELE SANDERS and \\ MARGARET W. FERGUSON
}

Literacy, in the sixteenth century, was construed as multiple, variable, subject to redefinition by edict from above and by practices from below. The importance of regulating changes in skills and behaviors, in particular, increased reading of the Bible, was hotly debated as the Reformation got underway. In England, the Tudor state intervened erratically, first encouraging the reading of the English Bible for all, then forbidding its reading to all but a privileged few. In 1538, every parish church was required by a royal injunction to purchase an English Bible and place it in the choir. ${ }^{1}$ The Great Bible, published in 1540 with a new preface by the Archbishop of Canterbury, stressed the ideal of an England peopled by 'all manner' of readers of Scripture in the vernacular: 'Here may all manner of persons, men, women, young, old, learned, unlearned, rich, poor, priests, laymen, lords, ladies, officers, tenants, and mean men, virgins, wives, widows, lawyers, merchants, artificers, husbandmen, and all manner of persons, of what estate or condition soever they be, may in this book learn all things'. ${ }^{2}$ Only three years later, however, in 1543, the selfvauntingly named Act for the Advancement of True Religion and for the Abolishment of the Contrary attempted to undo that opening of the floodgates by lowering them again to allow for only a trickle of elite readers to have access to Scripture. Reading the Bible in English was prohibited outright for women, artificers, journeymen, serving-men of the rank of yeoman and under, husbandmen and laborers; noblewomen and gentlewomen could read the Bible silently; only noblemen, gentlemen, and merchants were permitted to read it aloud to others. ${ }^{3}$

The contradictions of that early effort to police reading and writing, the contentitiousness of it signaled by backtracking on earlier initiatives, provide a window onto the topic of this special issue of Critical Survey and its theme of literacies in early modern England. 
The interjecting of social categories into the debate over scriptural literacy indicates the breadth and complexity of concerns stimulated by greater access to books by a greater portion of the population. In the emerging brave new world of cheap print and increasingly widespread skills in decoding vernacular texts, who would be allowed to read what? And to whom? How would various social rubrics - sex, marital status, age, occupation, wealth and class - determine who would have entry to institutions in which books were read in more or less formally determined ways? The list of no less than twenty-two different categories of potential Bible readers (men and women, young and old, learned and unlearned, etc.) invoked by Archbishop Thomas Cranmer illustrates by its exhaustiveness the mixed and uneven nature of the skills and approaches that reading designated at that time. In the hands of 'priests' or 'lawyers', in those of 'tenants and mean persons', or of 'virgins, wives, and widows', the Bible - or any other book - would have been read with different levels of fluidity, different accents, different purposes, assumptions, pleasures.

This volume presents a collaborative effort to investigate the implications of literacies (in the plural) for early modern culture. We speak here of 'literacies' because the phenomenon under scrutiny in these essays resists reduction to the kind of mono-lingual three R's (two R's if numeracy is excluded) often taken for granted today as a quantifiable standard for use in economic development programs, a standard for measuring uniform 'basic skills'. In early modern England, as the work of a growing number of scholars has shown, acquiring the ability to decipher, sound, and reproduce the letter of the emergent, not-yet-standardized national language was far more variegated, both in its procedures and in its results, than previously understood or acknowledged. Reading and writing took place in two stages, the second of which never arrived for the majority of young learners, those who would have had to abandon schooling for economic or ideological reasons about when they turned seven, the approximate age at which instruction in writing and the rudiments of Latin grammar began for the privileged rest (poorer children were expected to dedicate their labor to their families at that age; girls of all classes faced the additional hurdle of prescriptions discouraging female writing). ${ }^{4}$

Different type fonts and forms of script shaped different experiences of literacy. Letters learned by beginners were printed in Gothic type. Roman type, for them, was near-unreadable code. So, too, were various forms of handwriting, including the most common, italic and 
secretary, scripts more advanced writers alternated between or combined into a 'mixed hand' ${ }^{5}$ Factors such as these - varieties of script forms and type fonts, kinds of language instruction ranging from English-only to classical Latin and Greek, variable access to kinds of books and tiers of educational institutions - all helped the emergence of multiple literacies in this period: reading-only literacy, scribal-literacy, English-only literacy, vernacular foreign-language literacy, Latin-literacy, scriptural literacy, heraldic literacy, legal literacy, etc. Moreover, the relatively standardized English of the printing press, which helped serve the Protestant nationalist agenda of the Tudor state, still had to vie with rival languages, Irish and Welsh, and with its own regional variants. To illustrate that point, the printer William Caxton recounted the story of an English merchant who was rebuffed when he found himself in a different region of England and tried to purchase 'eggys' from a local household. ${ }^{6}$ The word meant nothing to the farmwife who answered the merchant by saying she didn't speak French (in her dialect the word was 'eyren'). As this anecdote conveys, a transaction as simple as the purchase of eggs between residents of different English shires could be frustrated by lack of a common vocabulary. English itself was multiple, a designation for a host of regional dialects that emerged as a national language only gradually through concerted efforts at standardization, uniform curricula, state supervision. Moreover, as Cranmer's crisscrossing categories - sex, marital status, age, occupation, wealth and class - of potential Bible readers indicates, the varied literacies of different social groups applied in overlapping ways to the same individuals. Early moderns found themselves at the interstices of competing languages, symbolic systems for writing and deciphering them, social, institutional and professional settings requiring particularized textual and linguistic competencies.

The work of our colleagues and our work in this area contributes to a still-forming field. Literacy studies, along with the related fields of the history of reading and the history of the book, center on a set of connected topics: acquisition of reading and writing, variable practices of those skills, books and documents as material artifacts. This domain is capacious enough to accommodate the work of scholars in many disciplines, both in the social sciences and in the humanities, and to foster as well an unusual degree of information sharing and collaboration between disciplines. From our particular vantage points within that larger field, literacy studies matter outside of the 
contribution they make to our knowledge about reading and writing as central cultural practices in the history of much of the world (nearly all of it if we include post-Colonial history). From where we stand, from our positions as teachers in departments of English, we believe that literacy studies matter also because of the new perspectives they bring to our understanding of familiar subjects (writers, readers) and objects (books, manuscripts) of literary studies. Materials and approaches made available through literacy studies are enabling crucial reconceptualizations of received literary tradition. As a growing body of research shows, works that literary scholars have always studied - poems, plays, prose romances, sermons, letters, diaries - take on new dimensions and meanings in the context of broader changes in language and society that shaped the writing, acquisition, circulation, and reading of such texts.

This questioning of literature via literacy has sparked disagreements and debate; it has also furthered among a number of scholars a consensus about several points. First, 'literacy' is in need of redefinition. The term requires updated explanation if it is to refer usefully to the specific configuration of practical skills, in potentially multiple languages, differentially valued, that reading and writing present in a given society. Second, literacy, if we use the singular to denote the phenomenon in a general sense, was in the early modern period a domain of social contest. Most of the population of Europe between the fourth and the eighteenth centuries was unable to read or write in any language; literacy conveyed status in sixteenth and early seventeenth-century England precisely because the majority lacked advanced instruction (schooling beyond the elementary level) at a time when ordinary dealings increasingly required it (selling livestock, answering legal charges, participating in local government, etc.). ${ }^{7}$ Finally, for all of the disparities it helped to consolidate, particularly with respect to those who lacked writing, literacy was also a source of unanticipated agency for readers. The market for books, partly responsive to the purchasing preferences of readers, gave book buyers some influence over titles and content; moreover, the uses to which readers put what they read were unpredictable, often contrary to expectations, implicit or explicit, on the part of authors or censors.

The essays in this volume present a diversity of perspectives on early modern literacies. Together, they illustrate the work of redefining literacy currently ongoing in the field. Mary Ellen Lamb's analysis of the play The Old Wives Tale challenges the notion that 
literacy and its social distribution can be understood in binary terms: literacy versus illiteracy, men versus women. She argues that that representation of literacy as a polarized phenomenon did not reflect a social reality but rather a social agenda. The very coinage 'old wives' tales' reflects a bias to promote Latinate classroom culture over and against the culture of oral narrative. In her view, literacy was a multiple phenomenon rather than a single one conceptually defined against 'illiteracy', not only because there were gradations of difference between more or less educated individuals, which were not keyed invariably to sex, but also because even the Latin-based grammar school was not impervious to oral culture, ballads and old wives tales, narratives linked with illiteracy and the illiterate. Works by writers ranging from George Peele to Philip Sidney and William Shakespeare testify to the lasting traces of orally-transmitted narratives even on minds schooled in humanist classrooms. Similarly, Janet Starner-Wright and Susan Fitzmaurice challenge the notion of a hard and fast divide between print and oral cultures. In their discussion of The History of Edward II, published in 1680 and believed by many modern critics to have been written by Elizabeth Cary, the authors argue that Cary, like other history writers of her day, draws upon conventions of print publishing interchangeably with those of traditional storytelling, mixing Latin phrases with proverbial sayings.

This destabilization of existing social and cultural categories by writers and readers shows why literacy was a site of contest. In her study of Roman capital letters, Bianca F.-C. Calabresi argues that uppercase letters, which evoke classical tradition and royal decrees, had the effect of bestowing dignity and high status on those who learned to form them (uppercase letters were considered an advanced skill that could be acquired only after mastering that of writing lowercase ones). To take the example of the forged letter that appears in Twelfth Night, Maria's use of Roman capitals in inscribing that document displays her social aspirations and, indeed, achieves them in part. As Elizabeth Rivlin also reminds us in her reading of The Comedy of Errors, the fact that literacy was perceived as a marker of hierarchy made it also an instrument for upsetting hierarchy. The drama, then, highlights the conflictual dimensions of literacy by heightening our sense of how ambiguous writing can be as a marker of position, hence how indeterminate or superficial also the nature of social standing itself. Judith Rose explains that among Quakers requiring women to write down their prophecies constituted a means 
of restricting their expression: 'once women's prophecies were written down, they could be censored, witheld, or circulated only in manuscript; they were therefore more manageable, less incendiary'. Following the Restoration, however, what had been a source of restriction during the Civil War era turned into a force for enabling women's expression when Quaker schools, unlike other educational establishments, included writing on the curriculum for girls. Ironically, innovations introduced as instruments for the containment of one generation provided another with tools for social mobility and intellectual training.

The shift in perspective that brings into clearer focus the activities of Quaker prophets, old wives and man servants, also brings to our attention the behaviors of readers, another previously under-examined category of participants in literate culture. Previously, only the author or the text (after the proverbial 'death of the author') was ascribed proprietary rights over meaning or play of meaning; more recently, due to the painstaking work of many scholars, the reader now is understood to have played a crucial role as well in working out the meanings texts accrued. Readers were not (and are not) passive recipients of content; they argued with the texts they read; they emended and corrected them, cut from the pages elements they found valuable or objectionable; they added to them their own owner marks, marginal comments, insignia, poems, unrelated notes and scribblings. ${ }^{8}$ Often, readers formed associations and at times larger social networks through their reading. In the roles of consumers, they exerted influence as well over textual production. As Jennifer Hellwarth demonstrates, early modern midwifery manuals give clear indication that their authors, male medical practitioners, though dismissive of midwives, nevertheless were reliant on a female readership for information and financial support. This point about the agency of the reader arises in a more figurative context in Rivlin's essay. She notes that one of the servants in Shakespeare's Comedy of Errors is shown at first to be a passive recipient of blows that inscribe his body as a text, as 'if the skin were parchment and the blows ... were ink' (3.1.13); however, the servant then asserts his own explanation of those marks - his own bodily text - and emerges as an independent reader-interpreter. The humor of the scene depends not only on the mercurial qualities of the identities of the two pairs of identical masters and identical servants but also on those of writing itself, at once indelible in its mark and unstable in its meaning. 
'Reading, viewing and listening', Roger Chartier has commented, 'are, in fact, so many intellectual attitudes which, far from subjecting consumers to the omnipotence of the ideological or aesthetic message that supposedly conditions them, make possible reappropriation, redirection, defiance, or resistance'. 9 The present collection of essays adds to our understanding of the subjective and social dimensions of literate practices, their availability to personal and communal adaptation and innovation. Scholars, as readers themselves, interpret newly texts that have been read differently before; in so doing, they redefine meanings and concepts in ways that may go against doxical or ideological definitions. The definitions of literacy emerging from current discussion among scholars in this field are multiple, provisional, and often counter-intuitive. They are opening conceptual territory for newly important types of evidence (the marked copy of a book rather than the clean copy, the margin along with the central text, the 'paratext' or prefatory materials preceding the 'main' text) and newly shared questions: is it possible to measure literacy with any precision if we define it to be multiple and compound? In early modern England, how did literate practices participate in the formation of the self? (And, in this age of computer literacy, how do they continue to do so to this day?) What is the relation between literacy and literature? These questions continue to be the work of many volumes and many scholars. They point the way to some larger implications of the multiple literacies documented here.

\section{Notes}

1. Joan Simon, Education and Society in Tudor England (Cambridge: Cambridge University Press, 1966), 175.

2. C. H. Williams, ed., English Historical Documents 1485-1558 (New York: Oxford University Press, 1967), 827.

3. H. S. Bennett, English Books and Readers: 1475 to 1557 (Cambridge: Cambridge University Press, 1970), 27.

4. W. J. Frank Davies, Teaching Reading in Early England, 1973; rpt. New York: Barnes \& Noble, 1974.

5. Keith Thomas, 'The Meaning of Literacy in Early Modern England,' in The Written Word: Literacy in Transition, ed. Gerd Baumann (Oxford: Clarendon Press, 1986), 97-131.

6. Margaret Ferguson discusses the anecdote and its implications for the linguistic diversity of English in her book, Dido's Daughters: Literacy, Gender and Empire in Early Modern England (Chicago: University of Chicago Press, 2002). Caxton tells the story in the 
preface to his translation of Virgil's Aeneid (Eneydos, as Caxton's title has it) published in 1490.

7. Keith Thomas points out that in early modern England, 'It ... became increasingly common to require that holders of local offices should be literate and to discharge them if they were not.' Moreover, literacy was an asset in commercial transactions as well, since 'anyone involved in business ran the risk of being cheated if he could not read a document or a set of accounts' ('The Meaning of Literacy in Early Modern England,' in The Written Word: Literacy in Transition, ed. Gerd Baumann [Oxford: Clarendon Press, 1986], 110).

8. In his 1473 English translation of a French collection of philosophers' sayings, The Dictes and Sayeings of the Philosophres, Caxton acknowledges the proprietary attitudes of contemporary readers toward their books when he recommends that any reader offended by certain misogynistic maxims of Socrates (omitted by the translator and reinserted by Caxton) simply remove that passage, 'wyth a penne race it out or ellys rente the leef oute of the booke'; for the reader's convenience, Caxton printed the passage as a detachable appendix at the back of the book (cited by Susan Schibanoff, 'Taking the Gold Out of Egypt: The Art of Reading as a Woman,' in Gender and Reading: Essays on Readers, Texts, and Contexts, eds. Elizabeth A. Flynn and Patrocinio P. Schweickart [Baltimore: The Johns Hopkins University Press, 1986], 85). Stephen Orgel provides the example of an owner of Holinshed's Chronicles who added to his copy heraldic shields of families figured in the narrative; a subsequent owner of the volume cut out some of the shields ('Records of Culture,' in Books and Readers in Early Modern England. Eds. Jennifer Andersen and Elizabeth Sauer [Philadelphia: University of Pennsylvania Press, 2002], 282-9).

9. Roger Chartier, Cultural History: Between Practices and Representations, trans. Lydia G. Cochrane (Ithaca, New York: Cornell University Press, 1988), 41. 